Botanica Marina

Vol. XIX, pp. 347-350, 1976

\title{
C:N Ratio in Some Marine Macrophytes and Its Possible Ecological Significance
}

\author{
F. X. Niell
}

Instituto de Investigaciones Pesqueras, Muelle de Bouzas, Vigo, Spain

(Received 27. 11.75)

\begin{abstract}
Carbon and nitrogen levels have been determined for 24 species of intertidal benthic algae from the northwest coast of Spain, by means of an automatic $\mathrm{C}, \mathrm{H}, \mathrm{N}$, combustion analyzer.. These are presented here as a carbon to nitrogen ratio. Brown algae showed the highest mean values among the non-calcified algae. The rate of production of a given alga and its C:N ratio shows an inverse relationship. There was no evident relationship between the level at which a given alga was growing in the intertidal, and the $C: N$ ratio. Older thallus parts showed a greater $C: N$ ratio than did younger parts.
\end{abstract}

\section{Introduction}

The hydrographical significance of $\mathrm{C}: \mathrm{N}$ ratios has been considered by a number of authors (Parsons and Strickland 1962, Provasoli 1963, Menzel and Ryther 1964, Trevaillon 1967, Flemmer and Biggs 1971, Quazim and Sankaranarayanan 1972, Banse 1974, and Fraga, in press), who have been concerned with the relationship between the levels of these elements in organisms and their recycling in aquatic habitats. Parsons et aL (1961) studied the organic composition of eleven planktonic algae cultured in the laboratory, and Mann (1972) has considered the $\mathrm{C}: \mathrm{N}$ ratio as related to phenological observations.

\section{Materials and Methods}

Twenty-four species of benthic algae were collected from intertidal rocks in Vigo Bay, N.W. Spain (Tab. 1). All collections were made during the last week of January, and were processed for analysis on the same day as they were collected. The plants were dried at $80^{\circ} \mathrm{C}$ for 3 hours, then ground manually to a homogeneous fine powder, and ultimately dried further at $100^{\circ} \mathrm{C}$. The dried and powdered samples were then introduced for combustion in a C, N, H, Perkin-Elmer 240 autoanalyzer. The accuracy of the analysis was verified by running known samples of glutamic acid and other amino acids (Fraga, in Press). The combustion temperature used was $840{ }^{\circ} \mathrm{C}$.

Multiple samples of the most important species (sense from Whittaker 1965) from the intertidal communities sampled were studied, so that an evaluation of statistical variation could be obtained.

\section{Results}

The percentages of dry matter separated into carbon (1), nitrogen (2), and hydrogen (3) along with the $\mathrm{C}: \mathrm{N}$ ratio (4) are presented in Figure 1. It will be seen that the amounts of carbon and nitrogen show a low positive correlation value ( $r$ equals 0.48 ). A graphic presentation of a regression analysis (according to the methods used by Fraga, in press) is shown in Figure 2. The formula derived from Figure 2 is that in the following equation:

$$
\mathrm{C}=5.39 \mathrm{~N}+12.43
$$

There were significant differences found between the $\mathrm{C}: \mathrm{N}$ ratio in the brown algae studied and other groups (Chlorophyta and Rhodophyta). The brown algae appear to have a lower nitrogen content than red and green algae (Fig. 1 and 2).

\section{Discussion}

Low $\mathrm{C}: \mathrm{N}$ ratios are characteristic of those phases in algal growth cycles when there is a rapid increase in biomass, while higher values pertain when there is low productivity. Mann (1972) found these same trends for Laminaria digitata and $L$. longicruris during favorable and unfavorable growth seasons.

It seems logical to infer that the position in which an intertidal alga is growing would influence the $\mathrm{C}: \mathrm{N}$ ratio because those at high intertidal sites would have thicker cell walls than those at lower less exposed levels. This seems to be the case for Pelvetia canaliculata, Fucus spiralis and Himanthalia elongata; however, greater $\mathrm{C}: \mathrm{N}$ ratios were found in species below or near the mean tide 
Tab. 1. Species collected for $\mathrm{C}, \mathrm{H}, \mathrm{N}$ analysis

\begin{tabular}{|c|c|c|c|c|c|}
\hline Code & Species & $\begin{array}{l}\text { Part of thallus used } \\
\text { in the analysis }\end{array}$ & $\begin{array}{l}\text { Number } \\
\text { of samp. }\end{array}$ & $\begin{array}{l}\text { Phenological stage in } \\
\text { time of collection }\end{array}$ & $\begin{array}{l}\text { Level of } \\
\text { collection }\end{array}$ \\
\hline & Chlorophyta: & & & & \\
\hline 1 & Enteromorpha ramulosa (Smith) Hooker & Whole thallus & 2 & Growth-pause & Low eulittoral \\
\hline 2 & Ulva gigantea (Kütz.) Bliding & Non reproductive part & 2 & Active growth & Low eulittoral \\
\hline 3 & $\begin{array}{l}\text { Enteromorpha compressa (L.) Greville } \\
\text { Phaeophyta: }\end{array}$ & Whole thallus & 2 & Active growth & Low eulittoral \\
\hline 4 & Pelvetia canaliculata (L.) Decaisne et Thuret & Vegetative & 4 & $\begin{array}{l}\text { Reproductive } \\
\text { growth-pause }\end{array}$ & High eulittoral \\
\hline 5 & Fucus spiralis $\mathrm{L}$. & Vegetative & 3 & $\begin{array}{l}\text { Reproductive } \\
\text { growth-pause }\end{array}$ & Middle eulittoral \\
\hline 6 & Himanthalia elongata (L.) S.F. Gray & Ribbon-shaped receptacle & 2 & Active growth & Low eulittoral \\
\hline $6^{r}$ & Himanthalia elongate (1.) S.F. Gray & Vegetative base & 2 & No growing part & Low eulittoral \\
\hline 7 & Laminaria saccharina Lamouroux & Lamina & 1 & Active growth & Low eulittoral \\
\hline 8 & Cystoseira tamariscifolia (Hudson) Papenfuss & s Vegetative perennial part & 1 & No growing perennial part & t Sublittoral \\
\hline 9 & Cystoseira baccata (Gmelin) Silva & Vegetative perennial part & 1 & No growing perennial part & t Sublittoral \\
\hline 10 & Laminaria ochroleuca La Pylaie & Stipe & 1 & Growth-pause & Sublittoral \\
\hline 10 & Laminaria ochroleuca La Pylaje & Lamina & 1 & Growth-pause & Sublittoral \\
\hline 11 & $\begin{array}{l}\text { Saccorhiza polyschides (Light.) Batters } \\
\text { Rhodophyta: }\end{array}$ & Lamina & 1 & Growth-pause & Low eulittoral \\
\hline 12 & Gelidium attenuatum (Turner) Thuret & Whole vegetative thallus & 1 & Growth-pause & Low eulittoral \\
\hline 13 & Gigartina acicularis (Wulfen) Lamouroux & Whole vegetative thallus & 2 & Growth-pause & Low eulittoral \\
\hline 14 & Gelidium sesquipedale (Turner) Thuret & Vegetative & 1 & Growth-pause & Low eulittoral \\
\hline 15 & Chondrus crispus (L.) Lyngbye & Vegetative & 3 & Beginning growth period & Low eulittoral \\
\hline 16 & Laurencia obrusa (Hudson) Lamouroux & Vegetative & 2 & Beginning growth period & Low eulittoral \\
\hline 17 & Gymnogongrus norvergicus (Gunner) J. Ag. & Vegetative & 2 & Beginning growth period & Low eulittoral \\
\hline 18 & Plocamium coccineum (Hudson) Lyngbye & Vegetative & 1 & Active growth & Low eulittoral \\
\hline 19 & Calliblepharis ciliata (Hudson) Kützing & Vegetative & 1 & Active growth & Low eulittoral \\
\hline 20 & Gracilaria confervoides (Linne) Greville & Vegetative & 1 & Active growth & Low eulittoral \\
\hline 21 & Laurencia pinnatifida Lamourous & Vegetative & 2 & Active growth & Low eulittoral \\
\hline 22 & Gastroclonium ovatum (Hudson) Papenfuss & Whole vegetative & 1 & Active growth & Low eulittoral \\
\hline 23 & Lithophyllum tortuosum (Esper) Foslie & Vegetative & 1 & Calcareous & Low eulittoral \\
\hline 24 & Corallina mediterranea Areschoug & Vegetative & 3 & Calcareous & Low eulittoral \\
\hline
\end{tabular}

${ }^{1}$ Unpublished data; ${ }^{2}$ Subrahamayan 1960 and $1961 ;{ }^{3}$ Lewis 1964

level such as Laminaria ochroleuca, Sacchoriza polyschides, as Enteromorpha intestinalis, Ulva rigida, Laminaria Cystoseira tamariscifolia and Cystoseira baccata, so that while intertidal position may influence the composition of some algae, not all algae respond in this way.

Studies on the productivity and phenology of benthic algae in Vigo Bay (Niell, unpublished) seem to be related to the analysis presented in Figure 1. All species having a winter period of dormancy such as Enteromorpha ramulosa, Sacchoriza polyschides, Laminaria ochroleuca, Cystoseira baccata, Cystoseira tamariscifolia, Fucus spiralis, Pelvetia canaliculata, Gelidium sesquipedale, Gelidium attenuatum, and Gigartina acicularis have high $\mathrm{C}: \mathrm{N}$ ratios compared with algae within the same Division not having this seasonal reproductive pattern. However, other species that were growing during the winter period saccharina, Himanthalia elongata, Chondrus crispus, Gymnogongrus norvergicus, Gracilaria confervoides, Plocamium coccineum, Gastroclonium ovatum, Laurencia pinnatifida and Laurencia obtusa showed lower values of $\mathrm{C}: \mathrm{N}$.

The carbon to nitrogen ratio is also an indicator in senescence in various tissues on the same algal thallus of Himanthalia elongata. Here old vegetative bases have significantly higher ratios than young ribboned thalli bearing reproductive cells (Tab. 1). The $\mathrm{C}: \mathrm{N}$ ratio in algae encrusted with calcium carbonate, such as the crustose corallines, averages higher values because of their special composition. 

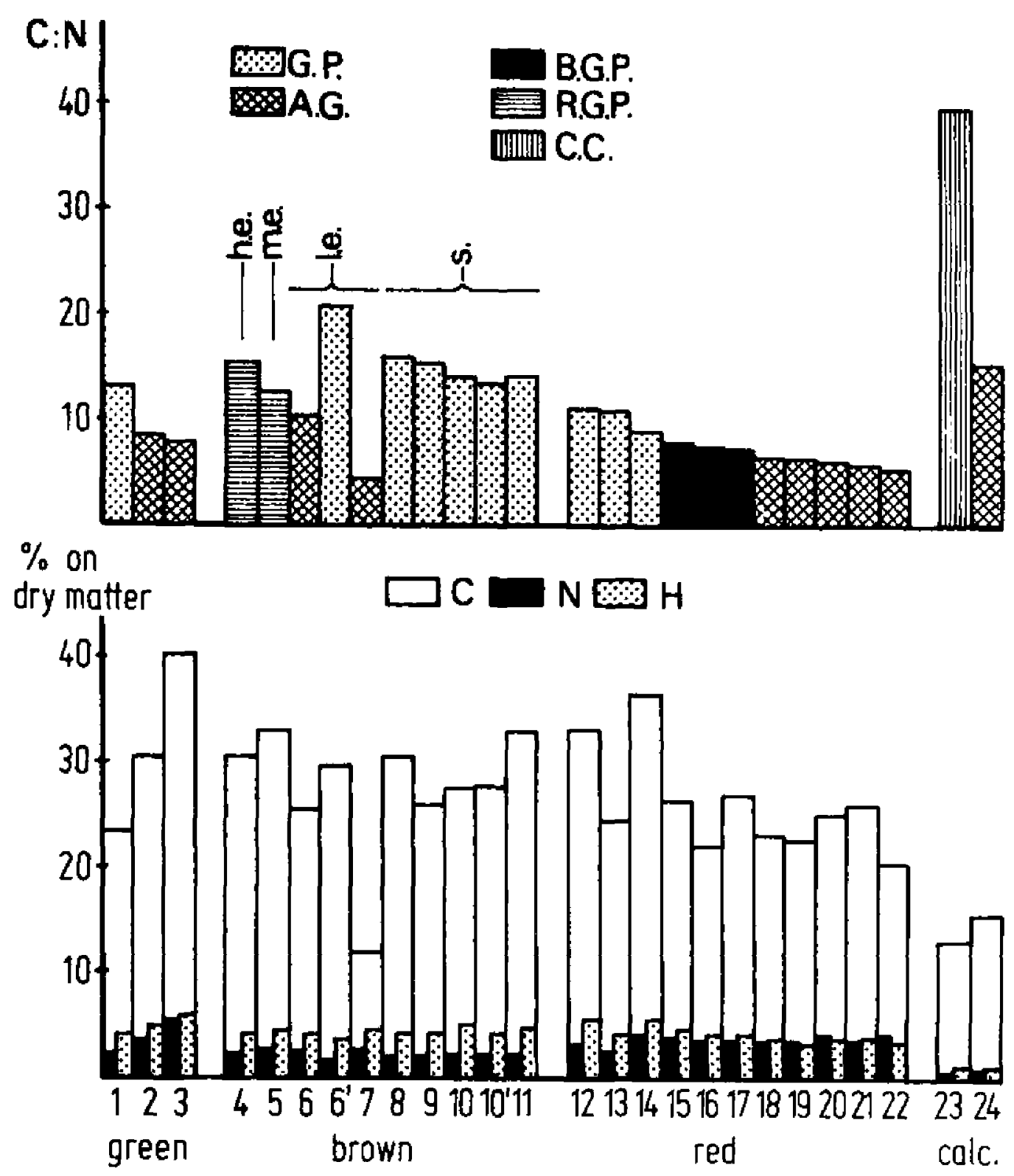

Fig. 1. Values of $\mathrm{C}, \mathrm{N}$ and $\mathrm{H}$ (down) in the species codified following Table 1 . On top $\mathrm{C}: \mathrm{N}$ values for the same species: $\mathrm{G} . \mathrm{P}=\mathrm{growth}$ pause period; A.G. = active growth period; B.G.P = beginning growth period; R.G.P = reproductive growth pause; C.C. = crustose calcareous; h.e. = brown algae collected in high eulittoral; m.e. = the same collected in low eulittoral; l.e. = the same collected in low eulittoral; $s=$ the same collected in subtidal.

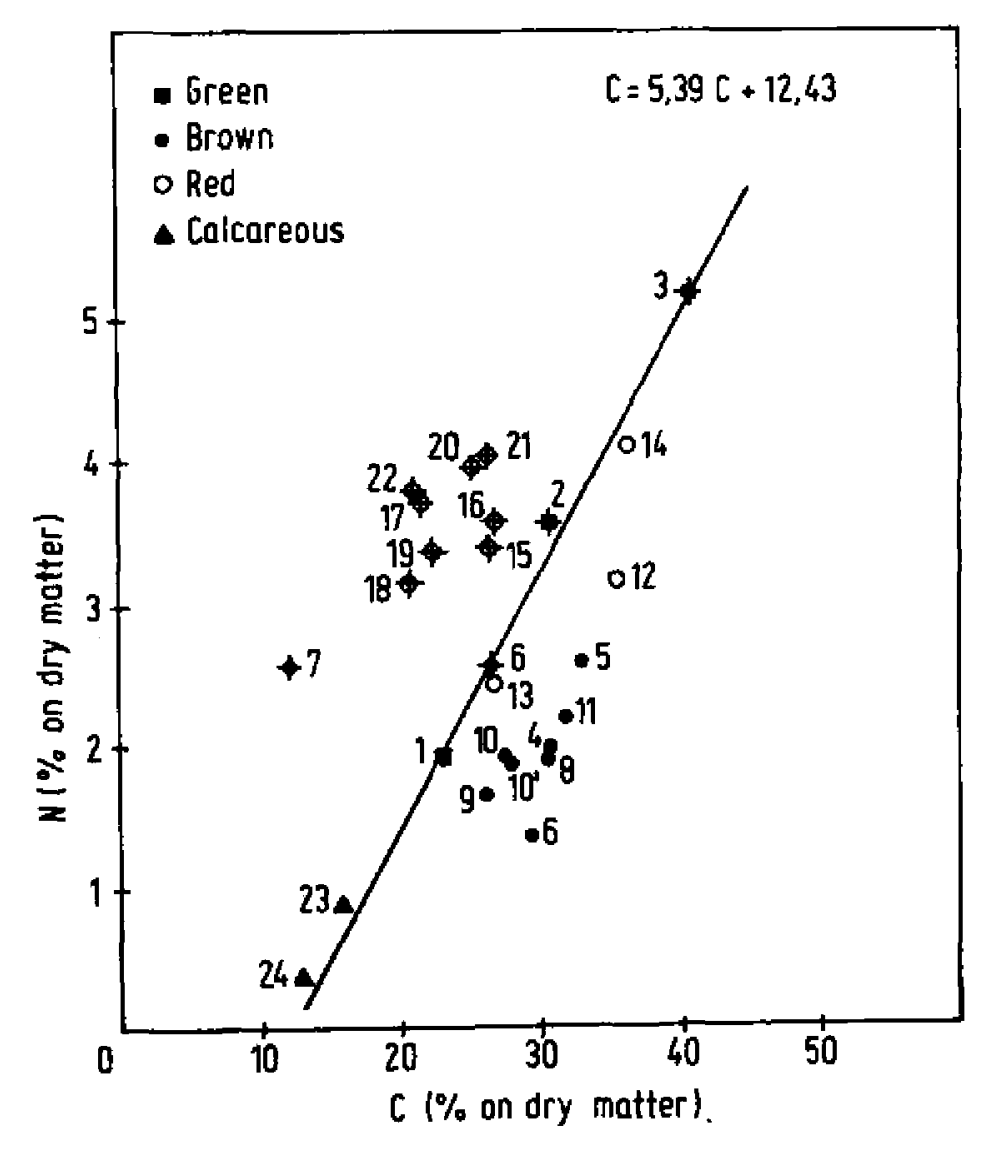

Fig. 2. Values of $C$ versus $N$ expressed as percents of dry matter. Symbols are crossed in the species growing activelly.

\section{Conclusions}

1. Carbon: Nitrogen ratios are distinctive in the algal groups studied, with higher values in the brown algae than those found in either the Chlorophyta or Rhodophyta.

2. The growth and reproduction of the seaweeds belonging at the same phyla coincides with variations in the carbon to nitrogen ratios. This finding is in agreement with the observations of Mann (1972), who also correlated intense growth periods with high $\mathrm{C}: \mathrm{N}$ ratios. Similarly, species in a dormant, or slow-growth period had lower $\mathrm{C}: \mathrm{N}$ values.

3. The older parts of the algae having persistent and not persistent thalli (Hemiphanerophytes in the sense of Feldmann 1951) present higher values than young occasional ones.

\section{Acknowledgements}

I wish to thank Prof. Dr. M. Neushul and Dr. Fraga for helpful discussions and criticism of the manuscript.

I would like specially to acknowledge Mrs. C. Mouriño who kindly carried out the analysis of the samples. 


\section{References}

Banse, K. 1974. On the interpretation of data for the carbon: nitrogen ratio of phytoplankton. Limnol Oceanogr. 19 (4): $691-700$.

Feldmann, J. 1951. Ecology of marine algae. In: G. M. Smith Manual of phycology: an introduction to the algae and their biology. 313-334.

Flemmer, D. A. and R. B. Biggs. 1971. Particulate carbon: nitrogen relations in northern Chesapeake Bay. J. Fish. Res, Bd. Can. $28(6): 912-918$.

Fraga, F. (in press). Distribución del carbono orgánico particulado en la región del afloramiento del N.W. de Africa y su relación con el nitrógeno particulado. I Marzo 1973.

Mann, K. H. 1972. Ecological energetics of the seaweed zone in a marine bay on the Atlantic coast of Canada. I. Zonation and biomass of seaweed. Mar. Biol. 14 (3): 199-209.

Menzel, D. W. and J. H. Ryther. 1964. The composition of particulate organic matter in the Westem North Atlantic. Limnol Oceanogr. 9:179-186.
Parsons, T. R., K. Stephens, and J. D. H. Strickland. 1961. On the chemical composition of eleven species of marine phytoplankters. J. Fish. Bd. Can. 18 (6): 1001-1016.

Parsons, T. R. and J. D. Strickland. 1962. Oceanic detritus. Science 136: 313-314.

Provasoli, L. 1963. Organic regulation of phytoplankton fertility. In: The Sea 2: 165-219. Ed. by M. N. Hill, London.

Quazim, S. Z. and V. N. Sankaranarayanan. 1972. Organic detritus of a tropical estuary. Mar. Biol 15 (3): 193-199.

Subrahamayan, R. 1960. Ecological studies on the Fucales. I. Pelvetia canaliculata. J. Ind. Bot. Soc. 35 (4): 378-390.

Subrahamayan, R. 1961. Ecological studies on the Fucales. II. Fucus spiralis L. J. Ind. Bot. Soc. 40 (3): 335-354.

Trevallion, A. 1967. An investigation of detritus in Southampton waters. J. Mar. Biol Ass. U.K. 43: 523-532.

Whittaker, R. H. 1965. Vegetation of the Great Smoky mountains. Ecol. Monogr. 26 (1): 1-80. 